\title{
TROPHIC INTERRELATIONS BETWEEN INTRODUCED COMMON CARP, CYPRINUS CARPIO (ACTINOPTERYGII: CYPRINIFORMES: CYPRINIDAE), AND FISH COMMUNITY IN A EUTROPHIC SHALLOW LAKE
}

\author{
Juan P. RAMÍREZ-HERREJÓN ${ }^{1}$, Rodrigo MONCAYO-ESTRADA ${ }^{2}$, Eduardo F. BALART ${ }^{1}$, \\ Luis A. GARCÍA CAMACHO ${ }^{3}$, Berenice VITAL RODRÍGUEZ ${ }^{3}$, Reyna ALVARADO \\ VILLANUEVA $^{3}$, Rosario ORTEGA MURILLO ${ }^{3}$, and Javier CARAVEO-PATIÑO ${ }^{1 *}$ \\ ${ }^{1}$ Centro de Investigaciones Biológicas del Noroeste (CIBNOR), Instituto Politécnico Nacional, \\ Playa Palo de Santa Rita Sur, La Paz, B.C.S., México \\ ${ }^{2}$ Centro Interdisciplinario de Investigación para el Desarrollo Integral Regional, \\ Instituto Politécnico Nacional, Unidad Michoacán (CIIDIR-Michoacán), COFAA, Jiquilpan, Michoacán, México \\ ${ }^{3}$ Laboratorio de Biología Acuática, Facultad de Biología, \\ Universidad Michoacana de San Nicolás de Hidalgo (UMSNH), Morelia, Michoacán, México
}

\begin{abstract}
Ramírez-Herrejón J.P., Moncayo-Estrada R., Balart E.F., García Camacho L.A., Vital Rodríguez B., Alvarado Villanueva R., Ortega Murillo R., Caraveo-Patiño J. 2014. Trophic interrelations between introduced common carp, Cyprinus carpio (Actinopterygii: Cypriniformes: Cyprinidae), and fish community in a eutrophic shallow lake. Acta Ichthyol. Piscat. 44 (1): 45-58.
\end{abstract}

Background. Introduction of the common carp, Cyprinus carpio Linnaeus, 1758, may cause a cascade of alterations in trophic webs, among other negative effects, indirectly due to its feeding behaviour. A simplified model site, covenient for studying such interrelations is Lago de Pátzcuaro, México, a shallow lake where carp was first introduced in 1974. The aim of our study was to characterize diet composition, diet breadth and trophic position of $C$. carpio and local fish fauna, and to assess diet overlap between fish fauna from sites with different habitat characteristics during the wet and the dry seasons.

Materials and methods. We assessed the diet of $C$. carpio and local fish fauna in six sites during the wet and the dry seasons. Stomach content analysis was carried out separately for each length class. The importance of each item was estimated by the index of relative importance (IRI) and the omnivory index was used to assess the feeding behaviour. The trophic guild and trophic position were determined using the TrophLab software and stable isotope analysis. Diet breadth was calculated by Levin's Index and diet overlap by the Horn's Index. Fish dorsal muscle and water hyacinth tissues were obtained from nitrogen isotope signature analysis.

Results. We found that $C$. carpio is an omnivorous fish that feeds in shallow areas with water hyacinth cover and rooted macrophytes, consuming mainly detritus and plant debris $(>60 \%)$. However, $\delta^{15} \mathrm{~N}$ values indicate that $C$. carpio is also a secondary consumer because it also ingests invertebrates associated with plant debris. The carp diet overlaps with native blackfin, Goodea atripinnis Jordan, 1880, at most sites. Small carp ( $<120 \mathrm{~mm}$ SL) overlapped with the Chirostoma spp. diet, as well as the introduced Oreochromis spp. at shallower sites with surface water hyacinth and with plant detritus at the bottom.

Conclusion. Lago de Pátzcuaro is facing trophic food web reduction that seems to be a more serious problem than feeding competition between the common carp and other fish species.

Keywords: Lentic systems, habitat characteristics, native species, trophic ecology, feeding interactions, gut content analysis, stable isotope analysis

\section{INTRODUCTION}

The common carp, Cyprinus carpio Linnaeus, 1758, is a fish species that has been widely introduced for farming and commercial fishing purposes. It was probably one of the first species to be dispersed by humans (Billard 1999, Vilizzi 2012) because its capability to establish itself readily in freshwater ecosystems in subtropical and temperate regions (Zambrano et al. 2006). In Mexico, common carp

\footnotetext{
* Correspondence: Dr Javier Caraveo-Patiño, Centro de Investigaciones Biológicas del Noroeste (CIBNOR), Instituto Politécnico Nacional 195, Col. Playa Palo de Santa Rita Sur, La Paz, B.C.S. 23096, México, phone +52 612-123-8484, fax: +52-612-125-3625, e-mail: (JCP) jcaraveo04@cibnor.mx, (JPRH) ramirezherrejon@gmail.com, (RME) rmoncayo@hotmail.com, (EFB) ebalart04@cibnor.mx, (LAGC)w_icho_beto@hotmail.com, (BVR) gueko_rana@hotmail.com, (RAV) alvareyna@yahoo.com, (ROM) rosaormu@yahoo.com.mx.
} 
was introduced and cultivated for human consumption as one of the solutions to increase animal-protein intake in rural human communities by national programs during the 1930s (Zambrano and Macías-García 2000). The common carp currently inhabits most freshwater systems of Mexico $(>80 \%)$ and is established in the larger lakes of central Mexico such as Lago de Chapala, Lago de Cuitzeo, Lago de Pátzcuaro, Lago de Yuriria, and Lago de Xochimilco (Anonymous 2010). Cyprinus carpio was released accidentally into Lago de Pátzcuaro in 1974 from aquaculture pens (Rosas 1976) and currently it is found throughout the lake with spatial segregation, with increased abundance in the southern zone (Ramírez Herrejón unpublished*).

The feeding behaviour of the common carp can cause increased sediment re-suspension and can directly affect fish habitat and destroy aquatic vegetation cover, and increasing water turbidity in shallow lakes (Zambrano et al. 2001, Leung et al. 2002, Scheffer et al. 2003, Özbay 2008). This kind of changes in habitat characteristics can indirectly cause a cascade of alterations on trophic webs (Khan 2003).

Cyprinus carpio is an omnivorous fish well adapted for bottom feeding; depending on the availability it can consume a wide range of small items like worms, molluscs, zooplankton, aquatic vegetation, plant debris, detritus, and insects (Summerfelt et al. 1971, Eder and Carlson 1977, Crivelli 1981, Powles et al. 1983, Chapman and Fernando 1994, Elías-Fernández and Navarrete-Salgado 1998, Colautti and Remes Lenicov 2001). The diversity of its diet makes this species resistant to food web change and capable of inhabiting a wide variety of habitats (Koehn 2004, Wolfe et al. 2009, Weber and Brown 2011). However, despite knowing the common carp feeding habits, understanding is limited regarding the trophic interrelations with the local fish biota co-inhabiting the lakes.

Lago de Pátzcuaro harbours native and introduced fish with different trophic specialization types such as, hervibores, carnivores (zooplanctivorous, insectivorous, and piscivorous) and omnivores (Rosas 1976, BerlangaRobles et al. 2002). The physical and chemical water properties of this lake are well described (Alcocer and Bernal-Brooks 2002) and their habitat too (RamírezHerrejón et al. 2013). For these reasons, we postulated that Lago de Pátzcuaro probably would be a good model for assessing trophic interrelations between common carp and the lake fish fauna as well as the associations of habitat characteristics with trophic interrelations. This study hypothesizes that $C$. carpio is a omnivorous generalist fish with a diet that overlaps with all fish taxa at all sites regardless of habitat characteristics. To test this hypothesis, we characterized diet composition, diet breadth, trophic position and diet overlap between fish fauna from sites with different habitat characteristics during the wet and the dry seasons.

\section{MATERIALS AND METHODS}

Study area. Lago de Pátzcuaro is located in the north- central part of the state of Michoacán, Mexico $\left(19^{\circ} 27^{\prime} \mathrm{N}\right.$, $101^{\circ} 26^{\prime} \mathrm{W}$ and $\left.19^{\circ} 44^{\prime} \mathrm{N}, 101^{\circ} 53^{\prime} \mathrm{W}\right) 2038 \mathrm{~m}$ above sea level (Fig. 1). The lake belongs to the hydrologic region of the Lerma-Chapala, as part of the Mexican Volcanic Belt. The lake surface has a maximum area of $116 \mathrm{~km}^{2}$ and a maximum depth of $12.2 \mathrm{~m}$ (Gomez-Tagle Chavez et al. 2002). The average depth is $4.9 \mathrm{~m}$, and watershed covers of $9340 \mathrm{~km}^{2}$ (Bravo-Espinosa et al. 2006). During September and November 2009 (wet season) and February and June 2010 (dry season), we sampled six sites the water properties (total dissolved solids, transparency, and turbidity) and habitat characteristics (depth, floating vegetation cover, and bottom type) as described by Ramírez-Herrejón et al. (2013):

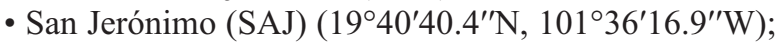

- Ucazanastacua (UCA) $\left(19^{\circ} 35^{\prime} 51.1^{\prime \prime} \mathrm{N}, 101^{\circ} 37^{\prime} 58.5^{\prime \prime} \mathrm{W}\right)$;

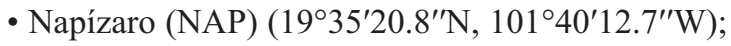

- Ihuatzio (IHU) $\left(19^{\circ} 35^{\prime} 35.1^{\prime \prime} \mathrm{N}, 101^{\circ} 40^{\prime} 45.2^{\prime \prime} \mathrm{W}\right)$ and;

- Embarcadero (EMB) $\left(19^{\circ} 33^{\prime} 0.6^{\prime \prime} \mathrm{N}, 101^{\circ} 37^{\prime} 30.7^{\prime \prime} \mathrm{W}\right)$ (Fig. 1).

The native ichthyofauna of the lake (Rosas 1976, Berlanga-Robles et al. 2002) includes: the carnivore bull-

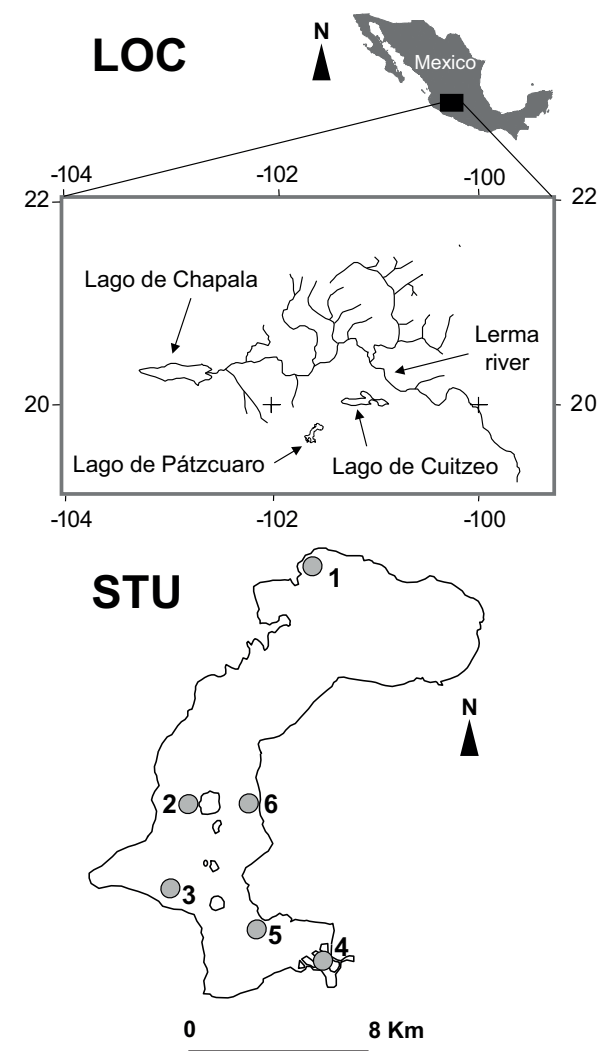

Fig. 1. Location of Lago de Pátzcuaro, Mexico (LOC) and study sites (STU): $1=$ San Jerónimo (SAJ), 2 = Ucasanastacua (UCA), 3 = Napízaro (NAP), 4 = Ihuatzio (IHU), $5=$ Embarcadero (EMB); Gray circles are the collection areas $(\sim 500 \mathrm{~m} \times \sim 100 \mathrm{~m})$; This map was taken and modified from Ramírez-Herrejón et al. 2013 and we thank for the reproduction permission given by the Revista de Biologia Tropical

\footnotetext{
${ }^{*}$ Ramírez Herrejón J.P. 2013. Ecología trófica de Cyprinus carpio y su relación con la estructura comunitaria de peces del Lago de Pátzcuaro, Michoacán. Doctorate
} thesis. Centro de Investigaciones Biológicas del Noroeste. La Paz, B.C.S., México 
dog goodeid, Alloophorus robustus (Bean, 1892) (insectivorous, piscivorous), the pike silverside, Chirostoma estor Jordan, 1880 (zooplanktivorous, insectivorous, piscivorous), the bigeye silverside, Chirostoma grandocule (Steindachner, 1894), the slender silverside, Chirostoma attenuatum Meek, 1902, the Patzcuaro silverside, Chirostoma patzcuaro Meek, 1902 (zooplanktivore), the Patzcuaro allotoca, Allotoca diazi (Meek, 1902) (zooplanktivorous, insectivore), the opal allotoca, Allotoca dugesii (Bean, 1887) (insectivore); the herbivore blackfin goodea, Goodea atripinnis Jordan, 1880, the olive skiffia, Skiffia lermae Meek, 1902, the omnivore Patzcuaro chub, Algansea lacustris Steindachner, 1895, and the lerma livebearer, Poeciliopsis infans (Woolman, 1894). Other introduced fish also inhabit the lake, such as the carnivore largemouth bass, Micropterus salmoides (Lacepède 1802) (zooplanktivorous, insectivorous, piscivorous) and the omnivore Oreochromis spp.

Fish sampling and trophic analysis. Fish were captured during the day (0800-1300 h) with two seines net, one (75 m long, $5 \mathrm{~m}$ wide, $10 \mathrm{~mm}$ mesh) to capture small sized fish $(<100 \mathrm{~mm}$ of standard length [SL]) and the other (150 m long, $9 \mathrm{~m}$ wide, $40 \mathrm{~mm}$ mesh) to capture large fish ( $>100 \mathrm{~mm} \mathrm{SL}$ ). Specimens were labelled and transported in ice to minimise enzymatic digestion (Cailliet et al. 1986). Standard length $[\mathrm{mm}]$, weight $[\mathrm{g}]$, and gastric repletion for each individual were measured. Fish were identified by species except individuals in the genera Oreochromis and Chirostoma. At least two species of Oreochromis were introduced to Lago de Pátzcuaro: blue tilapia, O. aureus (Steindachner, 1864) and Nile tilapia O. niloticus (Linnaeus, 1758) (see Gaspar Dillanes et al. 2000, Berlanga-Robles et al. 2002) but much hybridization has occurred, making positive identification at the species level difficult. Among Chirostoma, taxonomic differences between four native species and their taxonomic status are currently in dispute: $C$. grandocule, C. patzcuaro, $C$. attenuatum, and $C$. estor and one introduced species, the shortfin silverside, Chirostoma humboldtianum (Valenciennes, 1835). (Barriga-Sosa et al. 2002, Bloom et al. 2009), thereby making presently specific determination not possible. Accumulated prey diversity was measured, using Simpson's index for a finite population to determine the minimum number of guts to characterize the feeding habits of each fish taxa (Magurran 2004). We chose the Simpson's Index because it is a Type II index, or sensitive to changes in the more abundant taxa, and we want to emphasize the most representative food items than the rare or incidental prey. The curve became asymptotic at 12 individuals for Cyprinus carpio, 19 for Oreochromis spp., 15 for Chirostoma spp., 22 for Goodea atripinnis, and 8 for Alloophorus robustus. Fewer individuals by taxa at each site were not included in trophic analysis. We analyzed a total of 1744 specimens including all species, 938 guts during the wet season, and 806 during the dry season. A modified version of the quadrant method (Hynes 1950) for gut content analysis was used. Prey items were identified to equivalent taxa level
(Edmondson 1959, Pennak 1978). We only found remains of insects and it was not possible the identification of insects at a lower taxonomical level. A modified version of the index of relative importance (IRI) of Pinkas et al. (1971) proposed by Yáñez-Arancibia et al. (1976) was used:

$$
\mathrm{IRI}=F A \cdot 100^{-1}
$$

where: $F$ is the frequency of occurrence, and $A$ is the area, following Ramírez-Herrejón et al. (2013). This method is used when the gut content is constituted by small feeding components (diatoms, copepods, ostracods, rotifers, cladocerans) or when its quantification is not possible (detritus, plant debris) (Vega Cendejas 1990, Canto-Maza and Vega-Cendejas 2008). The graphical method using the $A[\%]$ and $F[\%]$ proposed by Costello (1990) and IRI expressed as percentages (Cortés 1997) were used to describe and compare easily the importance of prey. Individuals of small sized ( $<100 \mathrm{~mm} \mathrm{SL}$; Goodea atripinnis, Alloophorus robustus, Chirostoma spp.) were categorized in $5 \mathrm{~mm}$ intervals while large fish $(>100 \mathrm{~mm} \mathrm{SL}$; Cyprinus carpio, Oreochromis spp.) were categorized in $10 \mathrm{~mm}$ intervals to determine a probable diet change with fish growth. The standardized Levins' Index $\left(\mathrm{B}_{\mathrm{A}}\right.$ was used to calculate diet breadth (values from 0 to 1 ). Values of $\mathrm{B}_{\mathrm{A}}<0.60$ consider the fish to be specialists and a value of $\mathrm{B}_{\mathrm{A}}>0.60$ denotes a generalist fish (Krebs 1989). Feeding behaviour was described by the Omnivory Index (OI); it was calculated as the variance of the trophic levels of a consumer's preys (Christensen and Pauly 1992). The trophic level of each fish taxa was estimated using the TrophLab Program (Pauly et al. 2000). It includes the number of groups in the diet, the prey fraction of the diet (IRI\%), and the trophic level of the prey. The diet overlap between fish taxa was assessed with the index of Horn (Krebs 1989). Horn's index varies from 0 when there is no common use of feeding resources to 1.0 when there is complete resource overlap; it is considered as significant overlap when the value exceeds 0.60 (Wallace 1981). Some studies have argued that gut content analysis is biased because it considers ingested but not assimilated food (Bearhop et al. 2004). It is known that $\delta^{15} \mathrm{~N}$ is an accurate indicator of fish trophic position because it reflects assimilated food and shows progressive enrichment (3\% to 5\%o) from feeding components (Jardine et al. 2003). For this reason, the trophic position of each fish taxa was corroborated with nitrogen isotope analyses. Approximately $1 \mathrm{~g}$ of dorsal muscle tissue was obtained from fish (>30 mm SL) and frozen for later isotope analysis. Phytoplankton were obtained using a $64 \mu \mathrm{m}$ mesh net during dry and wet seasons, but these samples had important quantities of young zooplankton. Separation between phytoplankton and zooplankton was not accurate, for that reason $1 \mathrm{~g}$ of water hyacinth (Eichornia crassipes) root tissue was used to represent the primary productivity of lake. Stable isotope analysis was performed at the University of California-Davis Stable Isotope Facility. Nitrogen stable isotope ratios $\left(\delta^{15} \mathrm{~N}\right)$ are expressed in delta $(\delta)$ notation as parts per thousand (\%o). Mean standard error was $<0.1 \%$ for $\delta^{15} \mathrm{~N}$. We estimated the fish 
trophic position (TP) using $\delta^{15} \mathrm{~N}$ following Vander Zanden and Rasmussen (1999) equation:

$$
\mathrm{TP}=\left(\delta^{15} \mathrm{~N}_{\mathrm{S}}-\delta^{15} \mathrm{~N}_{\mathrm{PP}} \cdot \Delta_{\mathrm{TP}}\right)+1
$$

where; $\delta^{15} \mathrm{~N}_{\mathrm{S}}$ is the value of the fish tissue, and $\delta^{15} \mathrm{~N}_{\mathrm{PP}}$ is the value of primary productivity. We used $3.4 \%$ as trophic level enrichment $\left(\Delta_{\mathrm{TP}}\right)$, as reported by Vander Zanden et al. (2003). The information of Poeciliopsis infans about trophic guild, niche breadth, trophic position and stable isotope analysis were taken from RamírezHerrejón et al. (2013).

Data analysis. Non-parametric Kruskal-Wallis rank sumstest was used to detect differences of area of food items $\left(\mathrm{mm}^{2}\right), \delta^{15} \mathrm{~N}$ values, and trophic position among sites. Analyses were done for wet and dry seasons. The sum of the ranks was calculated for each group. Then the test statistic $H$ was calculated to represent the variance of the ranks among groups. But, if the null hypothesis is true, the $P$ value corresponding to $\chi^{2}$ equal to $H$ (McDonald 2009). For this reason, we use $\chi^{2}$ in the results. If significant differences were found, multiple post-hoc test comparisons were made using the Tukey-Kramer HSD — honestly significant difference - (Zar 1999). Both analyses were performed with JMP 3.1.6.2 software (SAS Institute).

Ethical issues. The presently reported study has been carried out in accordance with the Mexico's government regulations on experiments on animals.

\section{RESULTS}

We found 12 food items and about $90 \%$ of the guts were at least $50 \%$ full, ensuring a good description of the diet.

A total of 384 individuals of Cyprinus carpio from 30 to $450 \mathrm{~mm}$ SL were analyzed; 237 during the wet season and 147 during the dry season. We found nine food items. Individuals of $C$. carpio were grouped into three size classes (Table 1): $\mathrm{Cc} 1(<120 \mathrm{~mm} \mathrm{SL}), \mathrm{Cc} 2$ (120-230 mm SL), Cc3 ( $>230 \mathrm{~mm} \mathrm{SL})$. The three size groups were mainly distributed in the southern zone of the lake at Embarcadero (EMB) and Ihuatzio (IHU) during the wet and the dry season (Fig. 2).

Cyprinus carpio (Cc1) fed mainly on detritus (Table 2, Fig. 3). Zooplankton (copepods and cladocerans) were secondary items found during the wet season at all sites where it was present. Detritus and zooplankton were the preferred food at EMB and IHU during the dry season. Maximum amount (137.6 $\left.\pm 98.5 \mathrm{~mm}^{2}, 64 \%\right)$ of detritus was found at EMB during the wet season and $\left(47.1 \pm 29.3 \mathrm{~mm}^{2}, 66 \%\right)$ for zooplankton at IHU during the dry season. The smallest common carp showed intake variations by site on incidental items; they fed more plant debris in UCA $(31.4 \pm$ $\left.26.1 \mathrm{~mm}^{2}, 16 \%\right)$ than NAP $\left(0.4 \pm 1.8 \mathrm{~mm}^{2}, 0.4 \%\right)$ during the wet season $\left(\chi^{2}=13.25\right.$, degrees of freedom $(\mathrm{DF})=1$, $P<0.01)$ and more chironomids in NAP $\left(16 \pm 13.3 \mathrm{~mm}^{2}\right.$, $14 \%)$ than in UCA $\left(2.2 \pm 4.5 \mathrm{~mm}^{2}, 1 \%\right)$ during the wet season $\left(\chi^{2}=5.97, \mathrm{DF}=1, P<0.02\right)$. At this size the common carp was classified as omnivorous according to the IRI, Costello graph and OI (Table 2 and 3, Fig. 3).

Cyprinus carpio (Cc2) fed mainly on detritus and plant debris and secondary on zooplankton at EMB, IHU, NAP, and UCA during the wet and dry seasons, but filamentous algae and cladocerans were principally food items at SAJ where detritus and rotifers had secondary importance (Table 2, Fig. 3). The detritus recorded its maximum value $\left(142.4 \pm 81.7 \mathrm{~mm}^{2}, 71 \%\right)$ at EMB $\left(\chi^{2}=101.37, \mathrm{DF}=4, P<0.01\right)$ and $\left(12.6 \pm 9.1 \mathrm{~mm}^{2}, 23 \%\right)$ for zooplankton at SAJ $\left(\chi^{2}=67.19, \mathrm{DF}=4, P<0.01\right)$; during the wet season. Medium sized Cyprinus carpio fed principally on rotifers $\left(14.4 \pm 14 \mathrm{~mm}^{2}, 14 \%\right)$, fish scales $\left(15.2 \pm 21.2 \mathrm{~mm}^{2}, 15 \%\right)$, and detritus $\left(18.4 \pm 26.1 \mathrm{~mm}^{2}\right.$, $18 \%)$ in SAJ during the wet season $\left(\chi^{2}=25.73, \mathrm{DF}=4\right.$, $P<0.01)$. This size fish also fed more filamentous algae $\left(32 \pm 11.6 \mathrm{~mm}^{2}, 31 \%\right)$ and less insects $\left(19.3 \pm 4.6 \mathrm{~mm}^{2}\right.$, $5 \%)$ and plant debris $\left(19.3 \pm 4.6 \mathrm{~mm}^{2}, 11 \%\right)$ at SAJ during both seasons $\left(\chi^{2}=52.65, \mathrm{DF}=4, P<0.01\right.$, wet season; $\chi^{2}=145.42, \mathrm{DF}=3, P<0.01$, dry season). Chironomids consumption $\left(26.3 \pm 15.9 \mathrm{~mm}^{2}\right)$ was higher at NAP during the wet season $\left(\chi^{2}=41.04, \mathrm{DF}=4, P<0.01\right)$. At this size the common carp was classified as omnivorous according to the IRI, Costello graph and the OI (Table 2 and 3, Fig. 3).

Cyprinus carpio $(\mathrm{Cc} 3)$ fed mainly on detritus and secondary on plant debris, zooplankton; chironomids were incidental items at all sites during wet and dry season (Table 2). The detritus recorded its maximum value $\left(217 \pm 108.9 \mathrm{~mm}^{2}\right.$, $81 \%)$ at EMB during the wet season. The quantity of feeding resources consumed by the biggest sized carp was similar between sites in both seasons. At this size the common

Abundance of each food items by size of Cyprinus carpio in Lago de Pátzcuaro, Mexico

Table 1

\begin{tabular}{|c|c|c|c|c|c|c|c|c|c|c|}
\hline \multirow{3}{*}{ Food item } & \multirow{3}{*}{$\begin{array}{c}\text { Total } \\
\text { surface } \\
{\left[\mathrm{mm}^{2}\right]}\end{array}$} & \multirow{3}{*}{$\chi^{2}$} & \multirow{3}{*}{ DF } & \multirow{3}{*}{$P$} & \multicolumn{6}{|c|}{ Standard length class [mm] } \\
\hline & & & & & \multicolumn{2}{|l|}{$<120$} & \multicolumn{2}{|c|}{$120-230$} & \multicolumn{2}{|l|}{$>230$} \\
\hline & & & & & $\mathrm{mm}^{2}$ & $\%$ & $\mathrm{~mm}^{2}$ & $\%$ & $\mathrm{~mm}^{2}$ & $\%$ \\
\hline Copepods & 9506 & 41.24 & 2 & $<0.001$ & $34.7 \pm 28.7^{\mathrm{a}}$ & 64.50 & $14.7 \pm 19.7^{\mathrm{b}}$ & 27.32 & $4.4 \pm 8.8^{c}$ & 8.18 \\
\hline Cladocerans & 9978 & 30.95 & 2 & $<0.001$ & $32.9 \pm 29.9^{\mathrm{a}}$ & 60.37 & $15.7 \pm 19.6^{\mathrm{b}}$ & 28.81 & $5.9 \pm 10.4^{\mathrm{c}}$ & 10.83 \\
\hline Plant debris & 16592 & 10.94 & 2 & $<0.001$ & $23.46 \pm 38.1^{\mathrm{a}}$ & 15.64 & $45.07 \pm 49.57^{\mathrm{a}}$ & 30.06 & $81.39 \pm 50.53^{b}$ & 54.28 \\
\hline Detritus & 49816 & 26.33 & 2 & $<0.001$ & $52.6 \pm 46.7^{\mathrm{a}}$ & 19.61 & $80.7 \pm 67.8^{\mathrm{b}}$ & 30.09 & $134.9 \pm 92.7^{\mathrm{c}}$ & 50.30 \\
\hline
\end{tabular}

Cyprinus carpio $N=301 ; \chi^{2}=$ chi-squared test, $\mathrm{DF}=$ degrees of freedom; Abundance was estimated as $\mathrm{mm}^{2}$ in the quadrant method; Total surface = total surface represented by a food item; Abundance values are mean \pm standard deviation; Superscripts $a, b, c$ refer to differences in data variation between sites (Tukey-Kramer honestly significant difference [HSD] post hoc test, $P<0.05)$. 
carp was classified as omnivorous according to the IRI, Costello graph and the OI (Tables 2 and 3, Fig. 3).

Alloophorus robustus ingested mainly insects $(89.6 \pm$

$\left.54.1 \mathrm{~mm}^{2}, 92 \%\right)$ where $12 \%\left(20 \pm 14.2 \mathrm{~mm}^{2}\right)$ were chironomids (Table 2). This species was included in the present analysis only at SAJ during the wet season; it was determined to be carnivorous, according to the IRI and Costello graph (Table 2, Fig. 3).

We analyzed 133 individuals of Oreochromis spp. from 20 to $160 \mathrm{~mm} \mathrm{SL}, 62$ during the wet season and 71 during the dry season. Oreochromis spp. fed mainly on
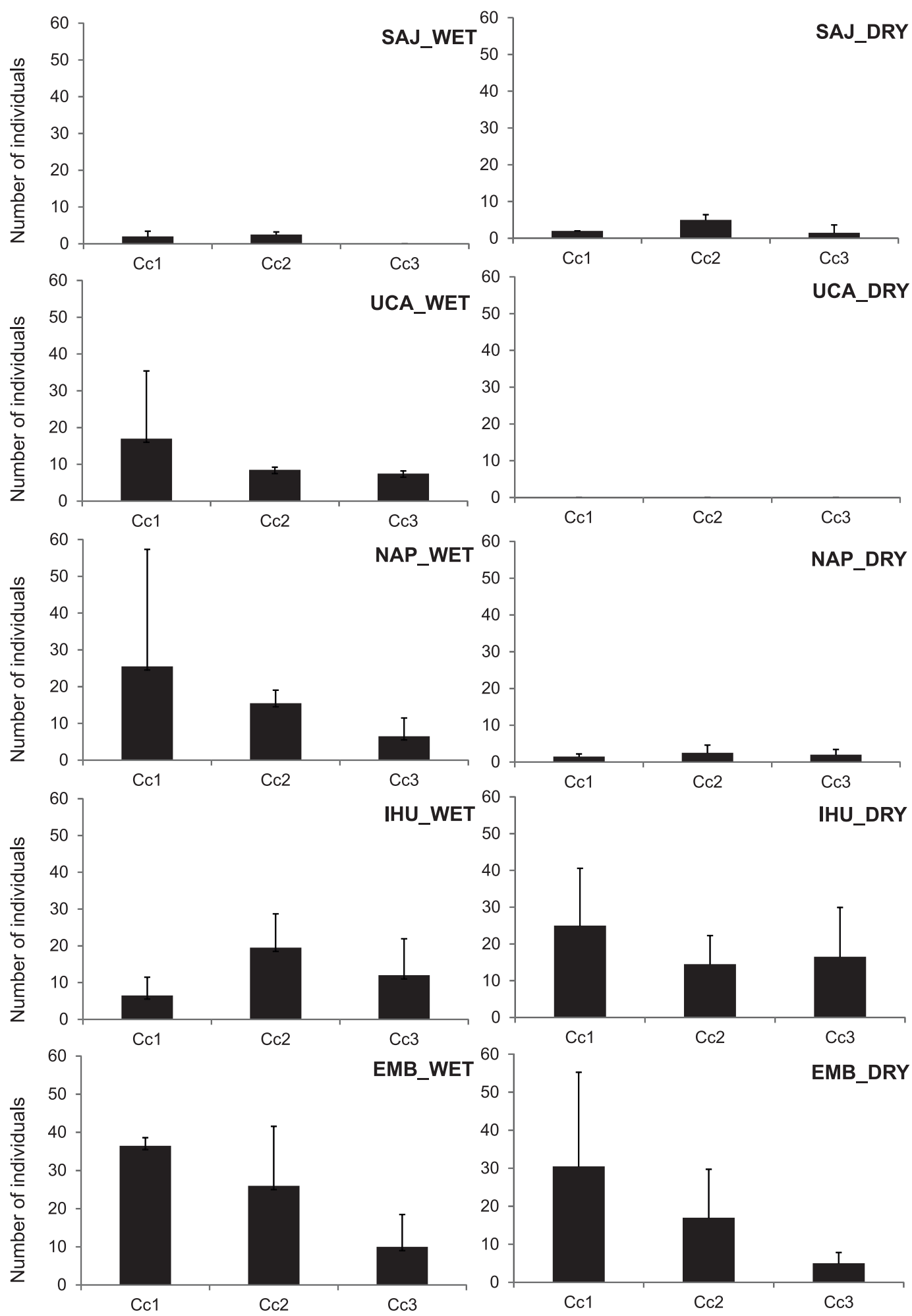

Fig. 2. Size frequency of the three size groups of Cyprinus carpio in five study sites in Lago de Pátzcuaro, Mexico, during wet (WET) and dry season (DRY); Cc1 = Cyprinus carpio $(<120 \mathrm{~mm} \mathrm{SL}), \mathrm{Cc} 2=$ Cyprinus carpio $(120-230 \mathrm{~mm}$ SL), Cc3 = Cyprinus carpio ( $>230$ mm SL), SAJ = San Jerónimo, UCA = Ucazanastacua, NAP = Napízaro, IHU = Ihuatzio, $\mathrm{EMB}=$ Embarcadero; Columns show the mean $\pm \mathrm{SD}$ of number of individuals 
detritus, secondary on filamentous algae, and zooplankton were incidental items during wet and dry season (Table 2). The detritus recorded its maximum value $\left(57.7 \pm 21.5 \mathrm{~mm}^{2}\right.$, $96 \%$ ) at NAP during the dry season. This species was determined to be omnivorous according to the IRI, Costello graph and the OI (Table 2 and 3, Fig. 3).

A total of 468 gut content of Chirostoma spp. from $35 \mathrm{~mm}$ to $70 \mathrm{~mm}$ SL was analyzed; 225 during the wet season and 243 during the dry season. Silverside fishes fed generally on copepods, cladocerans, scales, arachnids, and insects (Table 2, Fig. 3). The maximum value $\left(25.2 \pm 33 \mathrm{~mm}^{2}\right.$, $89 \%$ ) of zooplankton was found at EMB during the dry season and fish scales $\left(703.1 \pm 96.4 \mathrm{~mm}^{2}, 37 \%\right)$ at SAJ during the dry season. Chirostoma spp. consumed more cladocerans $\left(44.8 \pm 54.5 \mathrm{~mm}^{2}, 36 \%\right)$ at IHU $\left(\chi^{2}=85.19, \mathrm{DF}=4\right.$, $P<0.01)$ and more scales at NAP $\left(145.1 \pm 157.2 \mathrm{~mm}^{2}\right.$, $89 \%)$ during the dry season $\left(\chi^{2}=86.67, \mathrm{DF}=4, P<0.01\right)$. Silversides fed more chironomids at SAJ $\left(7 \pm 14.8 \mathrm{~mm}^{2}\right.$, $5 \%), U C A\left(5.7 \pm 12.5 \mathrm{~mm}^{2}, 4 \%\right)$, NAP $\left(7.5 \pm 36.5 \mathrm{~mm}^{2}\right.$, $5 \%)$ also during the wet season $\left(\chi^{2}=81.56, \mathrm{DF}=4\right.$, $P<0.01)$. Chirostoma spp. was determined to be carnivorous according to the IRI and Costello graph (Table 2, Fig. 3).

We analyzed 85 specimens of Goodea atripinnis from $30 \mathrm{~mm}$ to $120 \mathrm{~mm}$ SL, 35 during the wet season and 50 during the dry season. G. atripinnis fed generally on fila- mentous algae, detritus, zooplankton, and insects (Table 2, Fig. 3). The filamentous algae recorded its maximum value $\left(28.2 \pm 40.9 \mathrm{~mm}^{2}, 77 \%\right)$ at IHU during the wet season, detritus $\left(29.6 \pm 11.8 \mathrm{~mm}^{2}, 67 \%\right)$ at SAJ during the wet season, zooplankton (36\%) at SAJ during the dry season and insects (12\%) at SAJ during the dry season. During the dry season $G$. atripinnis fed more on detritus $\left(37.3 \pm 18.4 \mathrm{~mm}^{2}, 18 \%\right)$ at $\mathrm{EMB}\left(\chi^{2}=31.3, \mathrm{DF}=5\right.$, $P<0.01)$, and more insects at SAJ $\left(7.3 \pm 4.6 \mathrm{~mm}^{2}, 12 \%\right)$ and IHU $\left(2.6 \pm 4.8 \mathrm{~mm}^{2}, 6 \%\right)\left(\chi^{2}=21.92, \mathrm{DF}=5\right.$, $P<0.01)$. Filamentous algae was important $\left(52 \pm 18.5 \mathrm{~mm}^{2}\right.$, $46 \%)$ in the diet at UCA and less $\left(5.2 \pm 8.4 \mathrm{~mm}^{2}, 20 \%\right)$ at $\mathrm{EMB}\left(\chi^{2}=19.53, \mathrm{DF}=5, P<0.006\right)$ during we season. G. atripinnis was determined to be omnivorous according to the IRI, Costello graph and the OI (Tables 2 and 3, Fig. 3).

Cyprinus carpio was categorized as a specialist according Levins' niche breadth when combining all sites and both seasons $(0.35 \pm 0.1)$ as well for any fish size $(\mathrm{Cc} 1=0.46 \pm 0.1 ; \mathrm{Cc} 2=0.33 \pm 0.1 ; \mathrm{Cc} 3=0.26 \pm 0.1)$. Oreochromis spp. and A. robustus were determined to be a specialist. Chirostoma spp. was a specialist during the wet season and a generalist only at SAJ and IHU during the dry season. G. atripinnis behaved as a generalist only at UCA during the wet season and at SAJ and NAP during the dry season (Table 4).

Index of relative importance (IRI) [\%] for each food item per fish species by site during wet

Table 2 and dry seasons in Lago de Pátzcuaro

\begin{tabular}{|c|c|c|c|c|c|c|c|c|c|c|c|c|}
\hline & & Copepods & Cladocerans & Rotifers & Ostracods & Fish scales & Insects & Chironomids & Diatoms & $\begin{array}{l}\text { Filamentous } \\
\text { algae }\end{array}$ & Plant detritus & $\begin{array}{l}\text { Organic } \\
\text { matter }\end{array}$ \\
\hline \multirow{4}{*}{ 壳 } & $\mathrm{Cc} 2$ & $1.33[10.71]$ & $21.06[8.82]$ & 11.97 & - & 8.43 & $2.66[2.36]$ & - & [4.83] & 44.35 & [9.03] & $10.20[64.25]$ \\
\hline & $\mathrm{Cx}$ & $59.44[29.51]$ & $28.36[27.44]$ & - & {$[5.71]$} & $10.01[37.34]$ & - & 2.19 & - & - & - & - \\
\hline & $\mathrm{Ga}$ & $0.91[23.11]$ & $18.52[12.92]$ & - & - & - & {$[11.55]$} & - & $2.72[5.15]$ & $11.15[26.26]$ & - & $67.70[21.01]$ \\
\hline & $\mathrm{Ar}$ & - & - & - & - & 0.6 & 84.21 & 12.03 & - & - & - & 3 \\
\hline \multirow{5}{*}{ 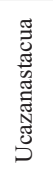 } & $\mathrm{Cc} 1$ & 15.7 & 14.45 & - & - & - & - & - & 1.74 & - & 13.7 & 54.41 \\
\hline & $\mathrm{Cc} 2$ & 8.22 & 8.49 & - & - & - & - & 3.11 & - & - & 18.19 & 61.99 \\
\hline & $\mathrm{Cc} 3$ & - & 1.95 & - & - & - & - & - & - & 2.54 & 20.1 & 75.41 \\
\hline & $\mathrm{Cx}$ & $59.76[37.49]$ & $35.88[36.62]$ & - & {$[2.04]$} & $3.03[17.93]$ & [5.92] & 1.35 & - & - & - & - \\
\hline & $\mathrm{Ga}$ & 10.64 & 11.35 & - & - & - & - & - & 20.57 & 46.1 & - & 11.35 \\
\hline \multirow{6}{*}{ 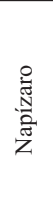 } & $\mathrm{Cc} 1$ & 20.78 & 12.54 & - & - & - & - & 11.91 & 2.59 & - & - & 52.19 \\
\hline & $\mathrm{Cc} 2$ & 8.23 & 9.49 & - & - & & - & 11.38 & - & 8.38 & 6.91 & 55.62 \\
\hline & $\mathrm{Cc} 3$ & - & - & - & - & - & - & 6.03 & - & - & 15.07 & 78.9 \\
\hline & $\mathrm{Ox}$ & $2.92[1.41]$ & $4.29[2.28]$ & - & - & - & - & - & 8.81 & $19.06[1.34]$ & - & 64.92 [94.96] \\
\hline & $\mathrm{Cx}$ & $89.21[28.02]$ & $9.41[25.42]$ & - & {$[2.01]$} & [41.44] & [3.11] & 1.38 & - & - & - & - \\
\hline & $\mathrm{Ga}$ & $1.28[15.69]$ & $2.40[11.36]$ & - & - & - & - & - & 9.77 [2.93] & 59.58 [41.90] & - & 26.97 [28.12] \\
\hline \multirow{6}{*}{$\begin{array}{l}\stackrel{ }{\mathbb{N}} \\
\text { 莺 }\end{array}$} & $\mathrm{Cc} 1$ & $21.87[31.65]$ & $22.71[33.77]$ & - & - & - & - & - & 1.96 & $2.15[4.73]$ & $4.09[6.35]$ & $47.03[23.50]$ \\
\hline & $\mathrm{Cc} 2$ & $8.49[8.03]$ & $7.78[9.71]$ & - & - & - & - & $1.72[5.07]$ & - & - & 23.34 [19.08] & $58.67[58.11]$ \\
\hline & $\mathrm{Cc} 3$ & {$[3.51]$} & $1.45[4.38]$ & - & - & - & - & $2.20[5.67]$ & - & 1.02 & $19.53[20.17]$ & $75.80[66.28]$ \\
\hline & Ox & $6.41[14.03]$ & 7.59 [3.04] & [13.09] & - & - & {$[1.75]$} & - & $7.25[6.72]$ & 23.62 [23.38] & - & 55.13 [37.99] \\
\hline & $\mathrm{Cx}$ & $14.46[8.73]$ & $15.37[31.62]$ & - & - & $2.77[11.64]$ & $67.39[48]$ & - & - & - & - & - \\
\hline & $\mathrm{Ga}$ & 8.08 [8.82] & $3.42[8.98]$ & [2.95] & - & {$[1.60]$} & {$[2.57]$} & - & $3.59[3.53]$ & $77.21[58.71]$ & - & $7.70[12.83]$ \\
\hline \multirow{6}{*}{ 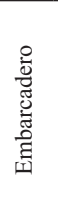 } & $\mathrm{Cc} 1$ & $8.55[26.81]$ & $11.85[24.24]$ & - & - & - & - & $2.56[1.53]$ & {$[2.22]$} & $4.14[6.91]$ & 8.17 [7.91] & $64.73[30.38]$ \\
\hline & $\mathrm{Cc} 2$ & 3.18 [6.39] & $2.94[8.36]$ & - & - & - & - & $1.85[4.28]$ & - & $1.37[2.40]$ & $19.19[25.62]$ & $71.46[52.95]$ \\
\hline & $\mathrm{Cc} 3$ & [1.38] & - & - & - & - & - & 1.31 & - & - & $17.65[33.63]$ & 81.05 [64.99] \\
\hline & $\mathrm{Ox}$ & $1.72[4.02]$ & $2.60[3.17]$ & 1.44 & - & - & - & - & 8.83 [9.47] & 17.01 [22.73] & - & $68.40[60.61]$ \\
\hline & $\mathrm{Cx}$ & $49.24[28.18]$ & $46.63[61.11]$ & - & - & $4.13[7.55]$ & - & [3.16] & - & - & - & - \\
\hline & $\mathrm{Ga}$ & [12.18] & $3.01[13.16]$ & $2.45[1.25]$ & - & [2.95] & - & - & $7.34[2.34]$ & $22.09[55.87]$ & - & $65.11[12.25]$ \\
\hline
\end{tabular}

Data from dry season are shown in square brackets; Cc1 = Cyprinus carpio $(<120 \mathrm{~mm} \mathrm{SL}), \mathrm{Cc} 2=$ Cyprinus carpio $(120-230 \mathrm{~mm}$ $\mathrm{SL}), \mathrm{Cc} 3=$ Cyprinus carpio (>230 mm SL), Ox = Oreochromis spp., Cx = Chirostoma spp., Ga = Goodea atripinnis, $\mathrm{Ar}=$ Alloophorus robustus. 
Cyprinus carpio at any of the three sized-groups was determined to be a primary consumer according to the TROPH Program during wet and dry season at all sites (Table 5). However, based on $\delta^{15} \mathrm{~N}$, C. carpio (Cc1) was considered as a secondary consumer at IHU and EMB during the wet and dry seasons; at $\mathrm{Cc} 2$ it was found to be
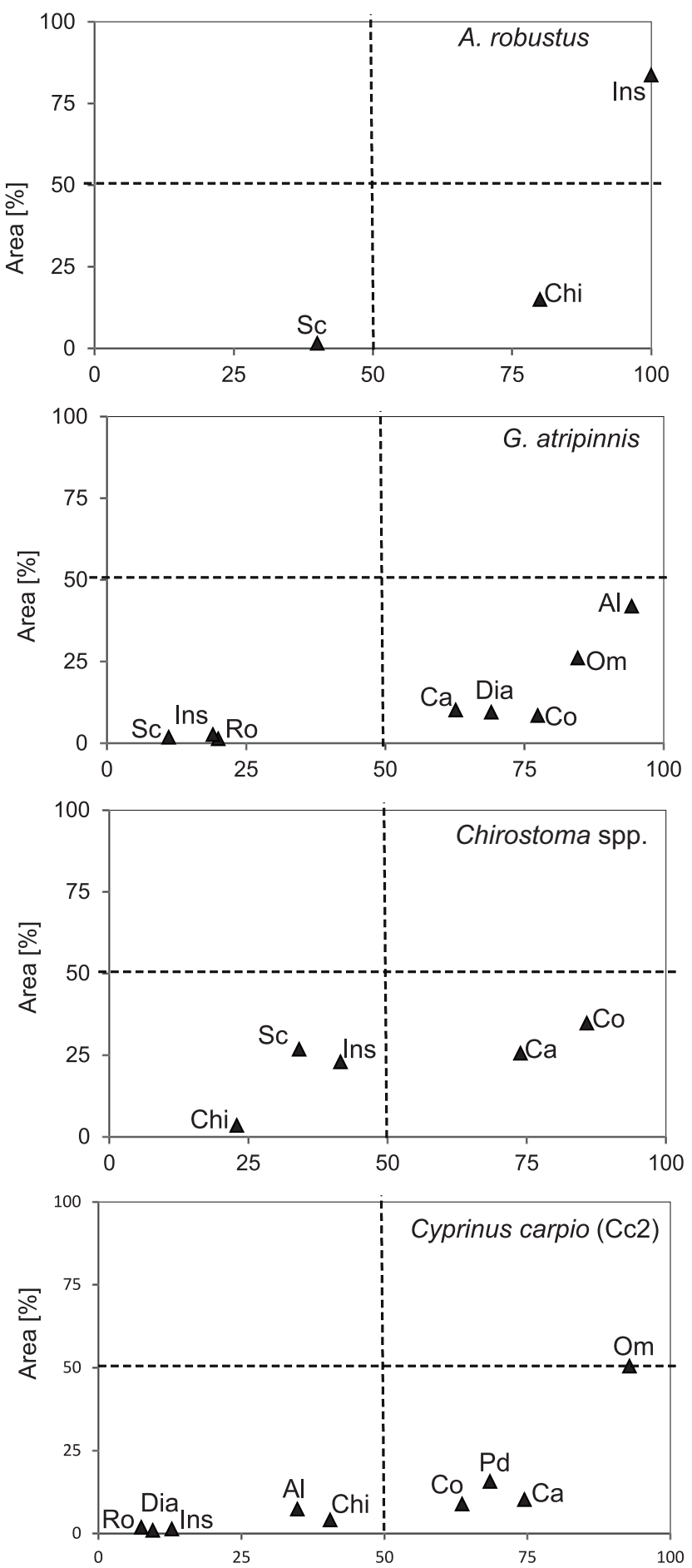

Frequence of Ocurrence [\%] a primary consumer only at SAJ in both seasons, and at Cc3 only at UCA during the wet season; in the other sites it behaved as a secondary consumer (Table 6). Chirostoma spp. was determined to be secondary consumer during the wet and dry seasons by TROPH Program and $\delta^{15} \mathrm{~N}$ analysis. Goodea atripinnis fall as pri-


Frequence of Ocurrence [\%]

Fig. 3. The importance of food items for all fish taxa in Lago de Pátzcuaro, Mexico, as determined by the Costello analysis; $\mathrm{Sc}=$ fish scales, $\mathrm{Chi}=$ Chironomids, Ins $=$ insects, $\mathrm{Pd}=$ plant detritus, $\mathrm{Ro}=$ rotifers, $\mathrm{Ca}=$ cladocerans, $\mathrm{Co}$ $=$ copepods, $\mathrm{Dia}=$ Diatoms, $\mathrm{Al}=$ filamentous algae, $\mathrm{Om}=$ organic matter 
mary consumer according to TROPH Program during the wet and dry seasons; based on $\delta^{15} \mathrm{~N}$, it behaved as a secondary consumer at IHU and EMB during the wet and dry seasons. The trophic position of Alloophorus robustus and Oreochromis spp. were similar using both TROPH Program and $\delta^{15} \mathrm{~N}$ (Table 5 and 6).

The $\delta^{15} \mathrm{~N}$ mean of water hyacinth root tissue was $8.2 \pm$ $0.3 \%$. The $\delta^{15} \mathrm{~N}$ mean of each fish taxa by site and both seasons are shown in Table 7. The $\delta^{15} \mathrm{~N}$ of muscle and trophic positions based on nitrogen isotopic signatures of Oreochromis spp. were higher at EMB during the dry season $\left(\chi^{2}=11.29\right.$, DF $=2, P=0.03$, in both analyses $)$ and was less at NAP during the wet season $\left(\chi^{2}=8.26, \mathrm{DF}=3\right.$, $P=0.04)$. For Chirostoma spp., the lowest value of $\delta^{15} \mathrm{~N}$ of muscle $\left(\chi^{2}=19.95, \mathrm{DF}=5, P<0.01\right)$ and trophic positions $\left(\chi^{2}=19.87, \mathrm{DF}=5, P<0.01\right)$ were at EMB (Tables 7 and 8). Goodea atripinnis had the highest value of $\delta^{15} \mathrm{~N}$ $\left(\chi^{2}=11.88, \mathrm{DF}=5, P=0.03\right)$ and trophic position $(P=0.03$, $\left.\mathrm{DF}=5, \chi^{2}=11.90\right)$ at EMB and the lowest at NAP. At
SAJ, the lowest value of $\delta^{15} \mathrm{~N}$ of muscle and trophic position were found during the wet season for C. carpio ( $\mathrm{Cc} 2)$ $\left(\chi^{2}=12.82, D F=3, P<0.01\right.$, both analyses $)$.

Cyprinus carpio (Cc2) diet overlapped with Goodea atripinnis at SAJ during both wet and dry season (Table 8). The three sizes of $C$. carpio overlapped its diet between themselves and with Poecilopsis infans at UCA during the wet season. At NAP and IHU, the three sizes of $C$. carpio overlapped its diet between each other, Oreochromis spp. and Poeciliopsis infans. Cyprinus carpio (Cc2) overlapped its diet with Goodea atripinnis at NAP during the wet season and $C$. carpio $(\mathrm{Cc} 1)$ at IHU during the dry season. At EMB, C. carpio ( $\mathrm{Cc} 1)$ overlapped its diet with all fish taxa during the dry season and C. carpio ( $\mathrm{Cc} 2$ and Cc3) with Oreochromis spp., Poeciliopsis infans and Goodea atripinnis during the wet season (Table 8).

Omnivory index for fish taxa by site during both seasons in Lago de Pátzcuaro, Mexico

Table 3

\begin{tabular}{|c|c|c|c|c|c|c|}
\hline & Site & $\mathrm{Cc} 1$ & $\mathrm{Cc} 2$ & $\mathrm{Cc} 3$ & Oreochromis spp. & Goodea atripinnis \\
\hline \multirow{5}{*}{ 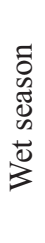 } & San Jerónimo & - & 0.31 & - & - & 0.39 \\
\hline & Ucazanastacua & 0.36 & 0.39 & 0.44 & - & 0.38 \\
\hline & Napízaro & 0.3 & 0.36 & 0.42 & 0.42 & 0.44 \\
\hline & Ihuatzio & 0.31 & 0.39 & 0.44 & 0.4 & 0.41 \\
\hline & Embarcadero & 0.37 & 0.42 & 0.44 & 0.43 & 0.43 \\
\hline \multirow{5}{*}{ 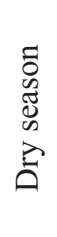 } & San Jerónimo & - & 0.38 & - & - & 0.32 \\
\hline & Ucazanastacua & - & - & - & - & - \\
\hline & Napízaro & - & - & - & 0.44 & 0.36 \\
\hline & Ihuatzio & 0.25 & 0.38 & 0.4 & 0.34 & 0.37 \\
\hline & Embarcadero & 0.29 & 0.39 & 0.44 & 0.42 & 0.36 \\
\hline
\end{tabular}

$\mathrm{Cc} 1=$ Cyprinus carpio $(<120 \mathrm{~mm} \mathrm{SL}), \mathrm{Cc} 2=$ Cyprinus carpio $(120-230 \mathrm{~mm} \mathrm{SL}), \mathrm{Cc} 3=$ Cyprinus carpio $(>230 \mathrm{~mm} \mathrm{SL})$.

Diet breadth for fish taxa by site during both seasons in Lago de Pátzcuaro, Mexico

\begin{tabular}{|c|c|c|c|c|c|c|c|c|}
\hline & & $\mathrm{Cc} 1$ & $\mathrm{Cc} 2$ & $\mathrm{Cc} 3$ & Oreochromis spp. & Chirostoma spp & $\begin{array}{c}\text { Goodea } \\
\text { atripinnis }\end{array}$ & $\begin{array}{c}\text { Alloophorus } \\
\text { robustus }\end{array}$ \\
\hline \multirow{5}{*}{ 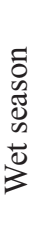 } & SAJ & - & 0.44 & - & - & 0.41 & 0.24 & 0.12 \\
\hline & UCA & 0.44 & 0.32 & 0.21 & - & 0.35 & 0.6 & - \\
\hline & NAP & 0.47 & 0.37 & 0.27 & 0.28 & 0.12 & 0.32 & - \\
\hline & IHU & 0.41 & 0.35 & 0.15 & 0.41 & 0.3 & 0.15 & - \\
\hline & EMB & 0.24 & 0.16 & 0.22 & 0.19 & 0.58 & 0.27 & 0.24 \\
\hline \multirow{5}{*}{ 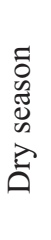 } & SAJ & - & 0.25 & - & - & 0.75 & 0.8 & - \\
\hline & UCA & - & - & - & - & 0.55 & - & - \\
\hline & NAP & - & - & - & 0.03 & 0.54 & 0.6 & - \\
\hline & IHU & 0.65 & 0.38 & 0.26 & 0.52 & 0.61 & 0.23 & - \\
\hline & EMB & 0.54 & 0.35 & 0.43 & 0.33 & 0.39 & 0.29 & 0.54 \\
\hline
\end{tabular}

$\mathrm{Cc} 1=$ Cyprinus carpio $(<120 \mathrm{~mm} \mathrm{SL}), \mathrm{Cc} 2=$ Cyprinus carpio $(120-230 \mathrm{~mm} \mathrm{SL}), \mathrm{Cc} 3=$ Cyprinus carpio $(>230 \mathrm{~mm} \mathrm{SL})$; $\mathrm{SAJ}=$ San Jerónimo, UCA = Ucazanastacua, NAP = Napízaro, IHU = Ihuatzio, EMB = Embarcadero. 


\section{DISCUSSION}

Cyprinus carpio behaves as an omnivorous fish in Lago de Pátzcuaro. Its food items can be detritus, primary producers and primary consumers. However, this species was classified not as generalist. This peculiar trophic situation derives from the benthic feeding behaviour of common carp; the shallow lake bottom is mainly covered by detritus and plant debris, which are the principal elements available in this eutrophic ecosystem. The similarity in stomach contents and nitrogen isotopic composition between $C$. carpio and fish fauna reveal no clear patterns of food resource partitioning that could be achieved through selective feeding. The common carp overlapped its diet in a significant way with all introduced fish taxa, with the native Goodea atripinnis at most sites, and with Chirostoma spp. at sizes below $120 \mathrm{~mm}$ SL. However, a trend was clear: diet overlapping was more evident at sites with high water turbidity $(>200 \mathrm{NTU})$, detritus $\left(\approx 100000 \mathrm{~m}^{3}\right.$ each year) and plant debris on the bottom, and water hyacinth on the surface $\left(\approx 44\right.$ plant individuals $\left.\cdot \mathrm{m}^{-2}\right)$.

Gut content analysis revealed that smaller sizes of C. carpio fed on zooplankton (ca. 50\%) and as it grows,

Trophic position for fish taxa — based on index of relative importance — during wet and dry

Table 5 season by site in Lago de Pátzcuaro, Mexico

\begin{tabular}{|c|c|c|c|c|c|c|}
\hline & Fish species & San Jerónimo & Ucazanastacua & Napízaro & Ihuatzio & Embarcadero \\
\hline \multirow{7}{*}{ 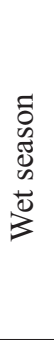 } & C. carpio $(\mathrm{Cc} 1)$ & - & $2.32 \pm 0$ & $2.47 \pm 0.13$ & $2.43 \pm 0.08$ & $2.25 \pm 0.07$ \\
\hline & C. carpio $(\mathrm{Cc} 2)$ & $2.45 \pm 0.21$ & $2.21 \pm 0.08$ & $2.30 \pm 0.13$ & $2.23 \pm 0.09$ & $2.08 \pm 0.06$ \\
\hline & C. carpio $(\mathrm{Cc} 3)$ & - & $2.02 \pm 0$ & $2.07 \pm 0.10$ & $2.04 \pm 0.06$ & $2.01 \pm 0.04$ \\
\hline & Chirostoma spp. & $2.95 \pm 0.17$ & $2.99 \pm 0.10$ & $3 \pm 0.04$ & $3.02 \pm 0.6$ & $2.88 \pm 0.04$ \\
\hline & G. atripinnis & $2.06 \pm 0.02$ & $2.22 \pm 0$ & $2.03 \pm 0$ & $2.06 \pm 0.01$ & $2.05 \pm 0.06$ \\
\hline & A. robustus & $3.16 \pm 0.4$ & - & - & - & - \\
\hline & Oreochromis spp. & - & - & $2.07 \pm 0$ & $2.09 \pm 0$ & - \\
\hline \multirow{6}{*}{ 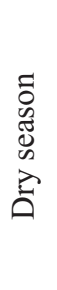 } & C. carpio $(\mathrm{Cc} 1)$ & - & - & - & $2.66 \pm 0$ & $2.53 \pm 0.06$ \\
\hline & C. carpio (Cc2) & $2.21 \pm 0.08$ & - & - & $2.24 \pm 0.09$ & $2.19 \pm 0.08$ \\
\hline & C. carpio (Cc3) & - & - & - & $2.15 \pm 0.1$ & $2.01 \pm 0$ \\
\hline & Chirostoma spp. & $2.85 \pm 0.31$ & $2.93 \pm 0.24$ & $2.80 \pm 0.34$ & $3.03 \pm 0.32$ & $2.97 \pm 0.16$ \\
\hline & G. atripinnis & $2.50 \pm 0.14$ & - & $2.27 \pm 0$ & $2.26 \pm 0.12$ & $2.29 \pm 0.1$ \\
\hline & Oreochromis spp. & - & - & $2.04 \pm 0$ & $2.35 \pm 0.16$ & $2.06 \pm 0.04$ \\
\hline
\end{tabular}

Values are mean \pm standard deviation; Cc1 = Cyprinus carpio $(<120 \mathrm{~mm} \mathrm{SL}), \mathrm{Cc} 2=$ Cyprinus carpio $(120-230 \mathrm{~mm} \mathrm{SL})$, Cc3 = Cyprinus carpio $(>230 \mathrm{~mm} \mathrm{SL})$.

Table 6

Trophic position for fish taxa during wet and dry season by site in Lago de Pátzcuaro (based on $\delta^{15} \mathrm{~N}$ )

\begin{tabular}{|c|c|c|c|c|c|c|}
\hline & Fish species & San Jerónimo & Ucazanastacua & Napízaro & Ihuatzio & Embarcadero \\
\hline \multirow{7}{*}{ 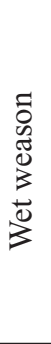 } & C. carpio $(\mathrm{Cc} 1)$ & - & $2.2 \pm 0^{\mathrm{a}}$ & $2.7 \pm 0.5^{\mathrm{a}}$ & $3.2 \pm 0.6^{\mathrm{a}}$ & $3.1 \pm 0.1^{\mathrm{a}}$ \\
\hline & C. carpio $(\mathrm{Cc} 2)$ & $1.6 \pm 0.8^{\mathrm{a}}$ & $3.0 \pm 0.3^{b}$ & $3.1 \pm 0.4^{b}$ & $3.4 \pm 0.1^{b}$ & $3.1 \pm 0.4^{b}$ \\
\hline & C. carpio $(\mathrm{Cc} 3)$ & - & $2.0 \pm 0.4^{\mathrm{a}}$ & $2.8 \pm 0.0^{\mathrm{a}}$ & $3.5 \pm 0.3$ & $3.3 \pm 0$ \\
\hline & Chirostoma spp. & $3.8 \pm 0.4^{\mathrm{a}}$ & $3.8 \pm 0.2^{\mathrm{a}}$ & $3.7 \pm 0.2^{\mathrm{a}}$ & $3.8 \pm 0.2^{\mathrm{a}}$ & $3.6 \pm 0.3^{\mathrm{a}}$ \\
\hline & G. atripinnis & $2.5 \pm 0.5^{\mathrm{ab}}$ & $2.4 \pm 0.2^{\mathrm{ab}}$ & $2.5 \pm 0.5^{\mathrm{b}}$ & $2.8 \pm 0.2^{\mathrm{ab}}$ & $3.2 \pm 0.3^{\mathrm{a}}$ \\
\hline & A. robustus & $2.9 \pm 0.4$ & - & - & - & - \\
\hline & Oreochromis spp. & - & - & $1.5 \pm 0.5^{\mathrm{a}}$ & $2.6 \pm 0.3^{\mathrm{a}}$ & $2.7 \pm 0.2^{\mathrm{a}}$ \\
\hline \multirow{6}{*}{ 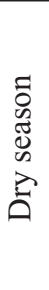 } & C. carpio $(\mathrm{Cc} 1)$ & - & - & - & $3.1 \pm 0.2$ & $3.2 \pm 0.1$ \\
\hline & C. carpio $(\mathrm{Cc} 2)$ & $2.2 \pm 0.6$ & - & - & $3.1 \pm 0.3$ & $3.1 \pm 0.2$ \\
\hline & C. carpio $(\mathrm{Cc} 3)$ & - & - & - & $3.5 \pm 0.3$ & $3.2 \pm 0$ \\
\hline & Chirostoma spp. & $4.3 \pm 0.4^{\mathrm{ab}}$ & $4.1 \pm 0.4^{\mathrm{ab}}$ & $4.1 \pm 0.3^{\mathrm{ab}}$ & $3.8 \pm 0.4^{\mathrm{bc}}$ & $3.7 \pm 0.5^{\mathrm{c}}$ \\
\hline & G. atripinnis & $2.7 \pm 0^{\mathrm{a}}$ & - & $2.7 \pm 0.2^{\mathrm{a}}$ & $3 \pm 0.4^{\mathrm{a}}$ & $2.6 \pm 0.7^{\mathrm{a}}$ \\
\hline & Oreochromis spp. & - & - & $1.7 \pm 0.1^{\mathrm{a}}$ & $2.3 \pm 0.2^{\mathrm{a}}$ & $2.7 \pm 0.1^{\mathrm{b}}$ \\
\hline
\end{tabular}

Values are mean \pm standard deviation; Cc1 = Cyprinus carpio $(<120 \mathrm{~mm} \mathrm{SL}), \mathrm{Cc} 2=$ Cyprinus carpio $(120-230 \mathrm{~mm} \mathrm{SL})$, Cc3 = Cyprinus carpio $(>230 \mathrm{~mm} \mathrm{SL})$; Superscripts $a, b$ refer to differences in data variation between sites (Tukey-Kramer honestly significant difference [HSD] post hoc test, $P<0.05)$. 
preferred to feed on hyacinth roots and plant detritus $(>60 \%)$. The nitrogen stable isotopes analysis showed that common carp can also ingested invertebrates associated to detritus and water hyacinth roots, a feeding practice recorded in "natural" lakes and rivers of different continents (Summerfelt et al. 1971, Eder and Carlson 1977, Crivelli 1981, Powles et al. 1983, Chapman and Fernando 1994, Elías-Fernández and Navarrete-Salgado 1998, Colautti and Remes Lenicov 2001) or highly modified systems as the Xochimilco canals in Mexico City (Zambrano et. al. 2010).

Evidence of the preference of the common carp for water hyacinth and rooted macrophytes as a preferred feeding habitat is the frequency of sizes found along the six study sites. The three groups of sizes of $C$. carpio were present during the wet and dry seasons at sites with higher aquatic vegetation coverage (IHU, EMB) located in the southern zone of the lake. And few individuals of common carp were captured at habitat with rocks at bottom and $<5 \%$ of floating aquatic vegetation cover (SAJ) located in the northern zone. In addition, at SAJ, plant debris was scarce in the gut of $C$. carpio. These findings agree with Britton et al. (2007) in the Lake Naivasha in Kenya, a shallow, warm and high productive lake. These authors argued that after carp initial establishment, the effects of benthic foraging by carp have not altered macrophytes regeneration, because the abundance of macrophytes is directly proportional to carp abundance.

Cyprinus carpio, Oreochromis spp., and Goodea atripinnis in Lago de Pátzcuaro are primary consumers that feed on the most abundant resources. The same occurs for Poeciliopsis infans (see Ramírez-Herrejón et al. 2013). Common carp fed mainly on the bottom (except for juvenile individuals $<100 \mathrm{~mm} \mathrm{SL}$ ), whereas $G$. atrip- innis and Oreochromis spp. on water column and bottom, and $P$. infans on bottom and periphyton. However, according to nitrogen stable isotopes $C$. carpio $(\mathrm{Cc} 1, \mathrm{Cc} 2$, $\mathrm{Cc} 3$ ) and $G$. atripinnis can be primary and secondary consumers since isotopic analysis show the assimilated food items, despite if these items were or not founded with gut content analysis (Jardine et al. 2003). This situation may be the common in degraded system. Conversely, Mercado-Silva et al. (2009) found in the Laja River system that in the reservoir itself, as well as the tail water exiting the reservoir, the common carp was located at the lowest trophic position, while in river ecosystems common carp where secondary consumers.

Fishes of the genus Chirostoma are known to be specialist that feed on invertebrates (Rosas 1976, García de León and Pérez-Velázquez 1996, Ross et al. 2006, Moncayo-Estrada et al. 2010). However, Chirostoma fishes in this study behaved as predacious with the capacity to behave as generalist during dry season, showing the aptitude to find its food items in different habitats (bottom, periphyton, surface and nekton) and in different trophic webs (nekton, periphyton and terrestrial). This multi-chain feeder behaviour has been described by Vadeboncoeur et al. (2005) for generalist predators that feed on different functional groups and has been found in other silversides (Contente et al. 2011, Strongin et al. 2011). In addition, such behaviour could be related to the analysis of all species together as Chirostoma. Omnivore fish as Poeciliopsis infans also show this type of behaviour in the Lago de Pátzcuaro (Ramírez-Herrejón et al. 2013). Chirostoma spp. and Alloophorus robustus were secondary consumers, the first fed mainly on zooplankton and insects and the second fed principally on insects. Stable isotope analysis located Chirostoma spp. also within tertiary

Table 7

Isotopic signatures of $\delta^{15} \mathrm{~N}$ for each fish taxa by site in Lago de Pátzcuaro during wet and dry season

\begin{tabular}{|c|c|c|c|c|c|c|}
\hline & Fish species & San Jerónimo & Ucazanastacua & Napízaro & Ihuatzio & Embarcadero \\
\hline \multirow{7}{*}{ 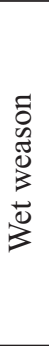 } & C. carpio $(\mathrm{Cc} 1)$ & - & $12.4 \pm 0^{\mathrm{a}}$ & $13.8 \pm 1.8^{\mathrm{a}}$ & $15.7 \pm 2.1^{\mathrm{a}}$ & $15.4 \pm 0.1^{\mathrm{a}}$ \\
\hline & C. carpio $(\mathrm{Cc} 2)$ & $10.1 \pm 2.8^{\mathrm{a}}$ & $15.1 \pm 1^{\mathrm{b}}$ & $20 \pm 1.4^{\mathrm{b}}$ & $16.4 \pm 0.3^{b}$ & $15.3 \pm 0.4^{b}$ \\
\hline & C. carpio $(\mathrm{Cc} 3)$ & - & $15.1 \pm 1.4$ & $14.3 \pm 0$ & $16.7 \pm 1$ & $15.9 \pm 0$ \\
\hline & Chirostoma spp. & $16.9 \pm 1.2^{\mathrm{a}}$ & $16.8 \pm 0.7^{\mathrm{a}}$ & $16.5 \pm 0.6^{\mathrm{a}}$ & $16.9 \pm 0.8^{\mathrm{a}}$ & $16.4 \pm 1.1^{\mathrm{a}}$ \\
\hline & G. atripinnis & $12.4 \pm 1.6^{\mathrm{ab}}$ & $12.2 \pm 0.8^{\mathrm{ab}}$ & $12.2 \pm 1.6^{\mathrm{b}}$ & $13.3 \pm 0.6^{\mathrm{ab}}$ & $14.8 \pm 1^{\mathrm{a}}$ \\
\hline & A. robustus & $13.9 \pm 1.4$ & - & - & - & - \\
\hline & Oreochromis spp. & $12.3 \pm 2.2^{\mathrm{ab}}$ & - & $10 \pm 1.5^{\mathrm{b}}$ & $13.8 \pm 0.9^{\mathrm{a}}$ & $14.2 \pm 0.2^{\mathrm{a}}$ \\
\hline \multirow{6}{*}{ 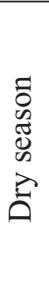 } & C. carpio $(\mathrm{Cc} 1)$ & - & - & - & $15.5 \pm 0.7^{\mathrm{a}}$ & $15.6 \pm 0.5^{\mathrm{a}}$ \\
\hline & C. carpio $(\mathrm{Cc} 2)$ & $12.4 \pm 1.9^{\mathrm{a}}$ & - & - & $15.3 \pm 1^{\mathrm{a}}$ & $15.5 \pm 0.7^{\mathrm{a}}$ \\
\hline & C. carpio $(\mathrm{Cc} 3)$ & - & - & - & $16.5 \pm 1.1^{\mathrm{a}}$ & $15.5 \pm 0^{\mathrm{a}}$ \\
\hline & Chirostoma spp. & $18.4 \pm 1.1^{\mathrm{ab}}$ & $18 \pm 1.5^{\mathrm{ab}}$ & $18 \pm 1^{\mathrm{ab}}$ & $16.9 \pm 1.5^{\mathrm{bc}}$ & $16.6 \pm 1.6^{\mathrm{c}}$ \\
\hline & G. atripinnis & $13 \pm 0^{\mathrm{a}}$ & - & $13 \pm 0.8^{\mathrm{a}}$ & $14 \pm 1.4^{\mathrm{a}}$ & $13.6 \pm 0.6^{\mathrm{a}}$ \\
\hline & Oreochromis spp. & - & - & $10.5 \pm 0.5^{\mathrm{a}}$ & $12.5 \pm 0.5^{\mathrm{a}}$ & $14.1 \pm 0.6^{\mathrm{b}}$ \\
\hline
\end{tabular}

Values are mean \pm standard deviation; Cc1 = Cyprinus carpio $(<120 \mathrm{~mm} \mathrm{SL}), \mathrm{Cc} 2=$ Cyprinus carpio $(120-230 \mathrm{~mm} \mathrm{SL})$, Cc3 = Cyprinus carpio (>230 mm SL); Superscripts $a, b$ refer to differences in data variation between sites (Tukey-Kramer honestly significant difference [HSD] post hoc test, $P<0.05)$. 
Table 8 consumers, coinciding with Moncayo-Estrada (2007)

Diet overlap between fish taxa by site during wet and dry (below the diagonal of the table) seasons in Lago de Pátzcuaro, Mexico

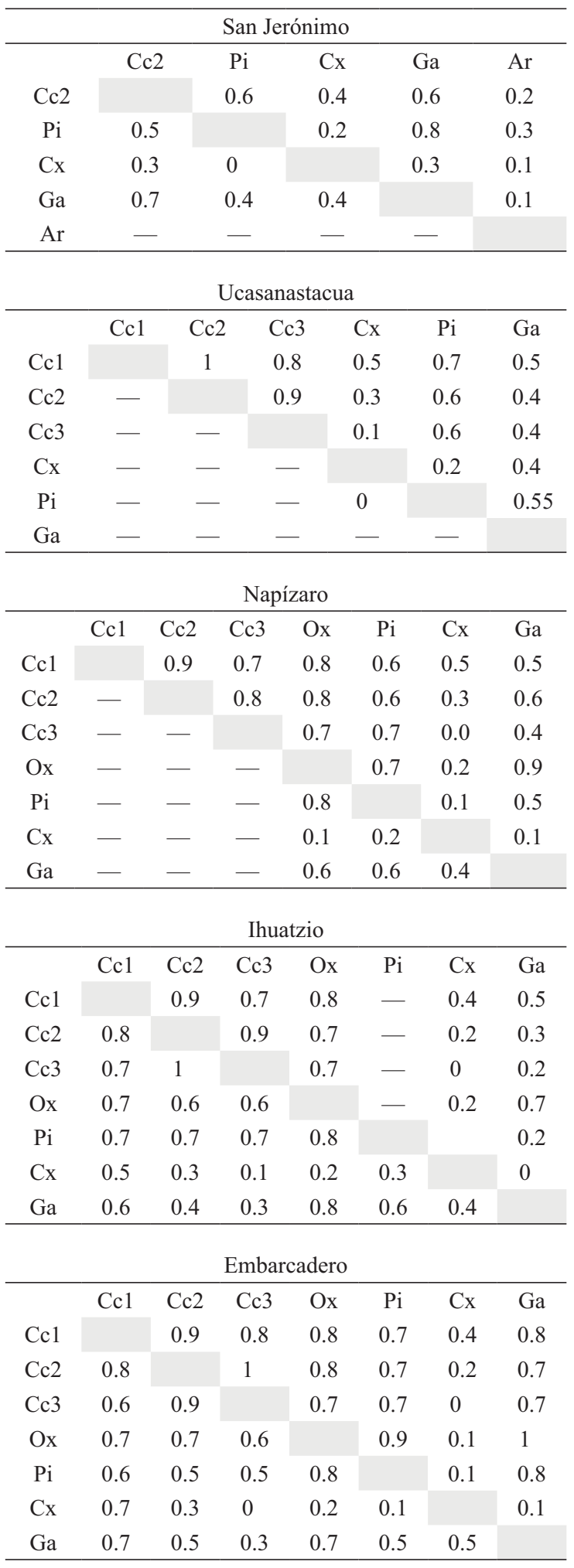

$\mathrm{Cc} 1=$ Cyprinus carpio $(<120 \mathrm{~mm} \mathrm{SL}), \mathrm{Cc} 2=$ Cyprinus carpio (120-230 mm SL), Cc3 = Cyprinus carpio (> $230 \mathrm{~mm} \mathrm{SL),}$ $\mathrm{Ox}=$ Oreochromis spp., $\mathrm{Pi}=$ Poeciliopsis infans, $\mathrm{Cx}=$ Chirostoma spp., $\mathrm{Ga}=$ Goodea atripinnis, $\mathrm{Ar}=$ Alloophorus robustus. analysis of Chirostoma lucius Boulenger, 1900 from a natural and an artificial system.

Diet overlapped substantially between common carp and local fish fauna, an aspect that suggests competition (Lampert and Sommer 2007). However, the shared fooditems are the most typically available in the lake. This result from the increasing eutrophication of the lake associated with the reduction of the water column and the increase of macrophytes where the water hyacinth is the predominant species (Huerto Delgadillo and Amador García 2011). This promotes the availability of feeding resources related to plant detritus in the southern zone of the lake. Water hyacinth cover has increased steadily in Lago de Pátzcuaro, from 9.8\% in 1970, before the carp introduction, $22 \%$ in 1990, to 35\% in 2000 (CalderónGarcía and Ángeles-López 1971, Chacón Torres 1993, Esteva and Reyes 2002). In other words, it seems the eutrophication process has lowered competition in the fish community by increasing the availability of a few food items associated to water hyacinth.

An important aspect to be taken into consideration is that, the native fishes in Lago de Pátzcuaro face not only impacts from introduced species, they are also threatened by human activities that has caused trophic and reproductive habitat destruction, a decrease in water quality, unprecedented plant detritus and sediment accumulation, depth loss and overfishing. All these facts also threaten the introduced species, and the decrease of the fisheries in this lake is a clear indicator. In Lago de Pátzcuaro fish capture volumes have declined from $\sim 2500 \mathrm{t}$ in 1988 to $<30$ t in 2007 (Anonymous 2010). Cyprinus carpio catches in Lago de Pátzcuaro have varied from $>600 \mathrm{t}$ in the 1980s (Gaspar Dillanes et al. 2000) to $<10 \mathrm{t}$ in 2009 (Zambrano et al. 2011).

The analyses of trophic ecology of the fishes suggest trophic web reduction in Lago de Pátzcuaro. We suggest that this problem is more serious than feeding competition between the common carp and other species. This food web alteration is evidenced by the low energy food items used by all species, the quantities of detritus found in the gut of most fish taxa, and the decline of top predator population such as native Chirostoma estor $(>170 \mathrm{~mm} \mathrm{SL})$ as well as the introduced largemouth bass, M. salmoides. In 1981 C. estor catches reached $136 \mathrm{t}$, but by 2000 catches dropped to only $4 \mathrm{t}$, and in 2006 catches represented only $1 \%$ of the total production of the lake (Rojas and Sasso 2006). The results suggest that all the fish, both native and introduced are trying to adapt and survive to the cumulative changes in the food web. However, presently with the data available it is still too difficult to separate the negative impacts of $C$. carpio on this ecosystem with affects caused directly or indirectly by anthropogenic activities.

\section{ACKNOWLEDGEMENTS}

The authors thank members of the Javier Alvarado Díaz Aquatic Biology Laboratory of Universidad Michoacana de San Nicolás de Hidalgo (UMSNH) spe- 
cially Omar Domínguez-Domínguez, María M. HerrejónAlmanza, and Juan J. Ramírez-Becerra for their logistical support; UMSNH students Adriana Torres, Lissette S. Castañeda, D. Montejo, Cesar E. Díaz, Valentín Mar, and Adán F. Mar; Ruben Quirino, Bonifacio Quirino, and Alejandro Quirino for assistance in fish collections; Dr. Miguel V. Cordoba-Matson of CIBNOR for editorial assistance. Thanks to Christian Silva-Bejarano, Noemí Bocanegra Castillo and Lucía Campos-Davila of CIBNOR for technical support. This work was funded by Comisión Nacional para el Conocimiento y Uso de la Biodiversidad (CONABIO project GN049 to JC-P) and the Coordinación de la Investigación Científica de la Universidad Michoacana de San Nicolás de Hidalgo (CIC-UMSNH-2009). J.P.R-H. is a recipient of a Consejo Nacional de Ciencia $\mathrm{y}$ Tecnología (CONACYT \#337465) doctoral fellowship. R.M-E. is supported by COFAA and EDI.

\section{REFERENCES}

Alcocer J., Bernal-Brooks F.W. 2002. Spatial and temporal heterogeneity of physical and chemical variables for an endorheic, shallow water body: Lake Pátzcuaro, México. Archiv für Hydrobiologie 155 (2): 239-253.

Anonymous 2010. Carta nacional pesquera Diario Oficial de la Federación 3: 17-18.

Barriga-Sosa I.L., Ibáñez-Aguirre A.L., ArredondoFigueroa J.L. 2002. Morphological and genetic variation in seven species of the endangered Chirostoma "humboldtianum species group" (Atheriniformes: Atherinopsidae). Revista de Biología Tropical 50 (1): 199-216.

Bearhop S., Adams C.E., Waldron S., Fuller R.A., MacLeod H. 2004. Determining trophic niche width: a novel approach using stable isotope analysis. Journal of Animal Ecology 73 (5):1007-1012. DOI: 10.1111/j.0021-8790.2004.00861.x

Berlanga-Robles C.A., Madrid-Vera J., Ruiz-Luna A. 2002. Fish abundance and trophic structure from the commercial catch in Lake Patzcuaro, Mexico. Hydrobiologia 467 (1-3): 117-122. DOI: 10.1023/A:1014965504486

Billard R. 1999. Carp: biology and culture. Springer-Praxis Publishing, Chichester, UK.

Bloom D.D., Piller K.R., Lyons J., Mercado-Silva N., Medina-Nava M. 2009. Systematics and biogeography of the silverside tribe Menidiini (Teleostomi: Atherinopsidae) based on the mitochondrial ND2 gene. Copeia 2009 (2): 408-417. DOI: $10.1643 / \mathrm{CI}-07-151$

Bravo-Espinosa M., Fregoso-Tirado L.E., Medina-Orozco L.E. 2006. Parámetros de erosionabilidad del modelo WEPP para andosoles con uso pecuario en la cuenca del Lago de Pátzcuaro, Michoacán. Técnica Pecuaria en México 44 (1): 129-141.

Britton J.R., Boar R.R., Grey J., Foster J., Logonzo J., Harper D.M. 2007. From introduction to fishery dominance: The initial impacts of the invasive carp Cyprinus carpio in Lake Naivasha, Kenya, 1999 to 2006. Journal of Fish Biology 71 (Supp. sd): 239-257. DOI: 10.1111/j.10958649.2007.01669.x

Cailliet G.M., Love M.S., Ebeling A.W. 1986. Fishes: A field and laboratory manual on their structure, identification, and natural history. Wadsworth, Belmont, CA, USA.
Calderón García A., Ángeles López J. 1971. Estudio del lirio acuático: Eichornia crassipes (Mart) Solms. en el Lago de Pátzcuaro, Michoacán-México. Comisión Forestal del Estado de Michoacán. Serie técnica 2.

Canto-Maza W.G., Vega-Cendejas M.E. 2008. Hábitos alimenticios del pez Lagodon rhomboides (Perciformes: Sparidae) en la laguna costera de Chelem, Yucatán, México. Revista de Biología Tropical 56 (4):1837-1846.

Chacón Torres A. 1993. Pátzcuaro un lago amenazado. Bosquejo Limnológico. Editorial Universitaria, Universidad Michoacana de San Nicolás de Hidalgo, Morelia, Michoacán, México.

Chapman G., Fernando C.H. 1994. The diets and related aspects of feeding of Nile tilapia (Oreochromis niloticus L.) and common carp (Cyprinus carpio L.) in lowland rice fields in northeast Thailand. Aquaculture 123 (3-4): 281-307. DOI: 10.1016/0044-8486(94)90066-3

Christensen V., Pauly D. 1992. ECOPATH II-a software for balancing steady-state ecosystem models and calculating network characteristics. Ecological Modelling 61 (3-4): 169-185. DOI: 10.1016/0304-3800(92)90016-8

Colautti D.C., Remes Lenicov M. 2001. Alimentación de la carpa (Cyprinus carpio Linnaeus 1758) en la Laguna de Lobos, Provincia de Buenos Aires, Argentina. Ecología Austral 11 (2): 69-78.

Contente R.F., Stefanoni M.F., Spach H.L. 2011. Feeding ecology of the Brazilian silverside Atherinella brasiliensis (Atherinopsidae) in a sub-tropical estuarine ecosystem. Journal of the Marine Biological Association of the United Kingdom 91 (Special Issue 06): 1197-1205. DOI: 10.1017/S0025315410001116

Cortés E. 1997. A critical review of methods of studying fish feeding based on analysis of stomach contents: application to elasmobranch fishes. Canadian Journal of Fisheries and Aquatic Science 54 (3): 726-738. DOI: 10.1139/f96-316

Costello M.J. 1990. Predator feeding strategy and prey importance: a new graphical analysis. Journal of Fish Biology 36 (2): 261-263. DOI: 10.1111/j.1095-8649.1990.tb05601.x

Crivelli A.J. 1981. The biology of the carp, Cyprinus carpio L., in the Camargue, southern France. Journal of Fish Biology 18 (3): 271-290. DOI: 10.1111/j.1095-8649.1981.tb03769.x

Eder S., Carlson C.A. 1977. Food habits of carp and white suckers in the South Platte and St. Vrain Rivers and Goosequill Pond, Weld County, Colorado. Transactions of the American Fisheries Society 106 (4): 339-346. DOI: 10.1577/1548-8659(1977)106<339:FHOCAW >2.0.CO;2

Edmondson W.T. (ed.) 1959. Fresh-water biology. 2nd edn. John Wiley and Sons, Inc, New York-London-Sydney.

Elías-Fernández G., Navarrete-Salgado N.A. 1998. Crecimiento y producción de carpa común (Cyprinus carpio Linaeus, 1758) durante la época de sequía y lluvias en un bordo del Estado de México, México. Hidrobiológica 8 (2):117-123.

Esteva J., Reyes J. 2002. El desarrollo social y ambiental en la región de Pátzcuaro, Centro de Estudios Sociales y Ecológicos (CESE), Michoacán, México.

García de León F.J., Pérez Velázquez H. 1996. Aspectos poblacionales de Chirostoma estor Jordan (Pescado blanco) y Micropterus salmoides Lacépède (Lobina negra) en el 
Lago de Pátzcuaro, Michoacán, México. Cuadernos Mexicanos de Zoología. Revista de la Sociedad Mexicana de Zoología 2 (1): 31-39.

Gaspar Dillanes M., Rojas P., Fernandez J.I., Diaz Rubin M.P. 2000. Lago de Pátzcuaro, Michoacán. Pp.165-194. In: Anonymous (ed.) Sustentabilidad y pesca Responsable en Mexico. Instituto Nacional de la Pesca (INP). Secretaria de Agricultura, Ganaderia, Desarrollo Rural, Pesca y Alimentacion (SAGARPA). Mexico City, Mexico.

Gomez-Tagle Chavez A., Bernal-Brooks F., Alcocer J. 2002. Sensitivity of Mexican water bodies to regional climatic change: three study alternatives applied to remote sensed data of Lake Patzcuaro. Hydrobiologia 467 (1-3): 169-176. DOI: $10.1023 / \mathrm{A}: 1014962831319$

Huerto Delgadillo R., Amador García A. 2011. Evaluación y análisis de la vegetación acuática y bases para su control. Pp 47-84. In: Huerto Delgadillo R., Vargas Velázquez S., Ortíz Paniagua C.F. (eds.) Estudio ecosistémico del Lago de Pátzcuaro. Aportes en gestión ambiental para el fomento del desarrollo sustentable. Instituto Mexicano de Tecnología del Agua, Universidad Autónoma del Estado de Morelos, Universidad Michoacana de San Nicolás de Hidalgo, Morelia, Michoacán, México.

Hynes H.B.N. 1950. The food of fresh-water sticklebacks (Gasterosteus aculeatus and Pygosteus pungitius) with a review of methods used in studies of the food of fishes. Journal of Animal Ecology 19 (1): 36-58. DOI: $10.2307 / 1570$

Jardine T.D., McGeachy S.A., Paton C.M., Savoie M., Cunjak R.A. 2003. Stable isotopes in aquatic systems: Sample preparation, analysis, and interpretation. Canadian Manuscript Report of Fisheries and Aquatic Sciences No. 2656.

Khan T.A. 2003. Dietary studies on exotic carp (Cyprinus carpio L.) from two lakes of western Victoria, Australia. Aquatic Science 65 (3): 272-286. DOI: 10.1007/s00027003-0658-5

Koehn J.D. 2004. Carp (Cyprinus carpio) as a powerful invader in Australia waterways. Freshwater Biology 49 (7): 882-894. DOI: 10.1111/j.1365-2427.2004.01232.x

Krebs J. 1989. Ecological methodology. 2nd edn. Harper and Row, New York, NY, USA.

Lampert W., Sommer U. 2007. Limnoecology: The ecology of lakes and streams. 2nd edn. Oxford University Press, Oxford, UK.

Leung B., Lodge D.M., Finnoff D., Shogren J.F., Lewis M.A., Lamberti G. 2002. An ounce of prevention or a pound of cure: Bioeconomic risk analysis of invasive species. Proceedings of Royal Society of London, series B: Biological Sciences 269 (1508): 2407-2413. DOI: 10.1098/rspb.2002.2179

Magurran A.E. 2004. Measuring biological diversity. Blackwell Science, Oxford, UK.

McDonald J.H. 2009. Handbook of biological statistics. 2nd edn. Sparky House Publishing, Baltimore, MD, USA.

Mercado-Silva N., Helmus M.R., Vander Zanden M.J. 2009. The effects of impoundment and non-native species on a river food web in Mexico's central plateau. River Research and Applications 25 (9): 1090-1108. DOI: 10.1002/rra.1205
Moncayo-Estrada R., Escalera-Gallardo C., López C., Lind O.T. 2007. Diet of Chirostoma lucius (Pisces: Atherinomorpha): seasonal trophic spectrum and ontogeny of piscivory. Southwest Nataturalist 52 (2): 229-233. DOI: 10.1894/0038-4909(2007)52[229:DOCLPA]2.0.CO;2

Moncayo-Estrada R., Lind O.T., Escalera-Gallardo C. 2010. Trophic partitioning of sympatric zooplanktivorous silverside in a tropical shallow lake: Fish morphometry and diet composition. Copeia 2010 (3): 431-436. DOI: 10.1643/CE08-024

Özbay H. 2008. An enclosure experiment to test the effects of common carp on the water quality in a shallow Turkish soda lake. Fresenius Environmental Bulletin 17 (12a): 2078-2082.

Pauly D., Christensen V., Froese R., Palomares M. 2000. Fishing down aquatic food webs. American Scientist 88 (1): 46-51. DOI: 10.1511/2000.1.46

Pennak W. 1978. Fresh water invertebrates of the United States. 2nd edn. John Willey and Sons, USA.

Pinkas L., Oliphant M.S., Iverson I.L.K. 1971. Food habits of albacore, bluefin tuna, and bonito in California waters. Fishery Bulletin No. 152.

Powles P.M., McCrimmon H.R., Macrae D.A. 1983. Seasonal feeding of carp, Cyprinus carpio, in the Bay of Quinte watershed, Ontario. Canadian Field Naturalist 97 (3): 293-298.

Ramírez-Herrejón J.P., Castañeda-Sam L.S., MoncayoEstrada R., Caraveo-Patiño J., Balart E.F. 2013. Trophic ecology of the exotic Lerma livebearer Poeciliopsis infans (Cyprinodontiformes: Poeciliidae) in the Lago de Pátzcuaro, Central Mexico. Revista de Biologia Tropical 61 (3): 1289-1300.

Rojas M.C., Sasso L.F. 2005. El pescado blanco. Revista Digital Universitaria, DGSCA-UNAM 6 (8): 1-18.

Rosas M. 1976. Datos biológicos de la ictiofauna del lago de Pátzcuaro, con énfasis en la alimentación del sus especies. Pp. 299-236. In: Anonymous (ed.) Memorias del Simposio sobre Pesquerías en Aguas Continentales, Tuxtla Gutiérrez, Chiapas, México.

Ross L.G., Martínez-Palacios C., Aguilar Valdez M., Beveridge M., Chavez Sánchez M. 2006. Determination of feeding mode in fishes: the importance of using structural and functional feeding studies in conjunction with gut analysis in a selective zooplanktivore Chirostoma estor estor Jordan 1880. Journal of Fish Biology 68 (6): 1782-1794. DOI: $10.1111 / j .1095-8649.2006 .01061 . x$

Scheffer M., Portielje R., Zambrano L. 2003. Fish facilitate wave resuspension of sediment. Limnology and Oceanography 48 (5): 1920-1926.

Strongin K., Taylor C.M., Roberts M.E., Neill W.H., Gelwick F. 2011. Food habits and dietary overap [sic] of two silversides in the Tennessee-Tombigbee Waterway: The invasive Menidia audens versus the Native Labidesthes sicculus. The American Midland Naturalist 166 (1): 224-233. DOI: 10.1674/0003-0031-166.1.224

Summerfelt R.C., Mauck P.E., Mensinger G. 1971. Food habits of the carp Cyprinus carpio L. in five Oklahoma reservoirs. Proceedings of the Annual Conference, 
Southeast Association of the Game and Fish Commissioners 24 (1970): 352-377.

Vadeboncoeur Y., McCann K.S., Vander Zanden MJ., Rasmussen J.B. 2005. Effects of multi-chain omnivory on the strength of trophic control in lakes. Ecosystems 8 (6): 682-693. DOI: 10.1007/s10021-003-0149-5

Vander Zanden M.J., Chandra S., Allen B.C., Reuter J.E., Goldman C.R. 2003. Historical food web structure and restoration of native aquatic communities in the Lake Tahoe (California-Nevada) basin. Ecosystems 6 (3): 274-288. DOI: $10.1007 / \mathrm{s} 10021-002-0204-7$

Vander Zanden M.J., Rasmussen J.B. 1999. Primary consumer $\delta^{13} \mathrm{C}$ and $\delta^{15} \mathrm{~N}$ and the trophic position of aquatic consumers. Ecology 80 (4): 1395-1404. DOI: 10.1890/00129658(1999)080[1395:PCCANA]2.0.CO;2

Vega Cendejas M.E. 1990. Interacción trófica entre los bagres Arius melanopus (Agassiz 1829) y Arius felis (Linnaeus, 1776) en las costas de Celestún Yucatán, México. Anales del Instituto de Ciencias del Mar y Limnología 17 (2): 271-285.

Vilizzi L. 2012. The common carp, Cyprinus carpio, in the Mediterranean region: origin, distribution, economic benefits, impacts and management. Fisheries Management and Ecology 19 (2): 93-110. DOI: 10.1111/j.1365-2400. 2011.00823.x

Wallace R.K.jr. 1981. An assessment of diet-overlap indexes. Transactions of the American Fisheries Society 110 (1): 72-76. DOI: 10.1577/1548-8659(1981)110<72:AAODI $>$ 2.0.CO;2

Weber M.J., Brown M.L. 2011. Relationships among invasive common carp, native fishes and physicochemical characteristics in upper Midwest (USA) lakes. Ecology of Freshwater Fish 20 (2): 270-278. DOI: 10.1111/j.1600-0633.2011. 00493.x

Wolfe M.D., Santucci V.J.jr., Einfalt L.M., Wahl D.H. 2009. Effects of common carp on reproduction, growth, and survival of largemouth bass and bluegills. Transactions of American Fisheries Society 138 (5): 975-983. DOI: 10.1577/T08-115.1

Yañez-Arancibia A., Curiel-Gómez J., de Yañez V.L. 1976. Prospección biológica y ecológica del bagre marino
Galeichthys caerulescens (Gunther) en el sistema lagunar costero de Guerrero, México (Pisces: Ariidae). Anales del Centro de Ciencias del Mar y Limnología 3 (1):92-125.

Zambrano L., Cordova Tapia F., Ramírez Herrejón J.P., Mar Silva V., Bustamante L., Camargo T., Bustamante E. 2011. Las especies exóticas en el lago de Pátzcuaro, Michoacán, México. Pp. 131-154. In: Huerto Delgadillo R., Vargas Velázquez S., Ortíz Paniagua C.F. (eds.) Estudio ecosistémico del Lago de Pátzcuaro. Aportes en gestión ambiental para el fomento del desarrollo sustentable. Instituto Mexicano de Tecnología del Agua, Universidad Autónoma del Estado de Morelos, Universidad Michoacana de San Nicolás de Hidalgo, Morelia, Michoacán, México.

Zambrano L., Macías-García C. 2000. Impact of introduced fish for aquaculture in Mexican freshwater systems. Pp. 113-124. In: Claudi R., Leach J.H. (eds.) Nonindigenous freshwater organisms: vectors, biology and impacts. Lewis Publishers, Boca Raton, FL. USA.

Zambrano L., Martínez-Meyer E., Menezes N., Towsend Peterson A. 2006. Invasive potential of common carp (Cyprinus carpio) and Nile tilapia (Oreochromis niloticus) in American fresh water systems. Canadian Journal of Fisheries and Aquatic Sciences 63 (9): 1903-1910. DOI: 10.1139/f06-088

Zambrano L., Scheffer M., Martínez-Ramos M. 2001. Catastrophic response of lakes to benthivorous fish introduction. Oikos 94 (2): 334-350. DOI: 10.1034/j.16000706.2001.940215.x

Zambrano L., Valiente E., Vander Zanden M.J. 2010. Stable isotope variation of a highly heterogeneous shallow freshwater system. Hydrobiologia 646 (1): 327-336. DOI: 10.1007/s10750-010-0182-2

Zar J.H. 1999. Biostatistical analysis. 4th edn. Prentice Hall, Upper Saddle River, NJ, USA.

Received: 12 June 2013

Accepted: 4 February 2014

Published electronically: 31 March 2014 